\title{
Kembali ke Akar: Pendidikan Kristen dalam Menghadapi Isu Perubahan Iklim, Perang, dan Keterbatasan Akses Pendidikan
}

\author{
Imbran Batelemba Bonde \\ Pondok Baca Rodo nDaya (Poso) \\ Email: imbran92bonde@gmail.com
}

\begin{abstract}
The $21^{\text {st }}$ century brings many changes that have never been in the previous century. Technology, takes a big enough role for human life. However, these advance are also accompanied by challenges that are unique to the $21^{\text {st }}$ century. This, also has a major impact on Christian Education, which in the end is faced with the threat of climate change, the danger of war or the other acts of violence, and also the lack of acces to education. Using the literary research method, this article will explore several written source, such as the Bible, books, and jurnals that discus the life of Jesus and the legacy of Christian theology in the addressing these three challenges whether they are directly related to these issues or use creative interpetation to look for pararells to the problem. In the end, Christian education, with an emphasis on the family, offers three important steps: reaching out and opening up, compassion, and caring for the environment, to overcome these three problems.
\end{abstract}

Keywords: Christian Education, Climate Change, War, The $21^{\text {st }}$ Century, Jesus.

\begin{abstract}
Abstrak
Abad 21 membawa banyak perubahan yang belum pernah di abad sebelumnya. Teknologi, mengambil peran yang cukup besar bagi kehidupan manusia. Namun, kemajuan tersebut, juga diikuti dengan tantangan yang khas abad 21. Hal ini, juga memberikan dampak yang besar bagi Pendidikan Kristen, yang pada akhirnya diperhadapkan pada ancaman perubahan iklim, bahaya perang atau tindakan kekerasan lainnya, dan juga minimnya akses pendidikan. Dengan menggunakan metode penelitian pustaka, artikel ini akan menelisik beberapa sumber tulisan, seperti Alkitab, buku, dan jurnal yang membahas kehidupan Yesus dan warisan teologi Kristen, dalam menyikapi ketiga tantangan tersebut, baik yang bersinggungan secara langsung dengan masalah tersebut, maupun menggunakan penafsiran kreatif untuk mencari kesejajaran pada masalah tersebut. Pada akhirnya, Pendidikan Kristen, dengan menitikberatkan pada keluarga, menawarkan tiga langkah penting: menjangkau dan membuka diri, belarasa, dan peduli terhadap lingkungan, untuk mengatasi ketiga masalah tersebut.
\end{abstract}

Kata-Kata Kunci: Pendidikan Kristen, Perubahan Iklim, Perang, Abad 21, Yesus.

\section{Pendahuluan}

Zaman semakin tak terprediksi.

Dunia yang merupakan tempat tinggal miliaran manusia, setiap harinya mengalami banyak perubahan. Teknologi berkembang begitu cepat. Kecerdasan buatan yang sedari awal dikembangkan 
oleh manusia, bahkan dalam kasus tertentu, telah mengalahkan kemampuan manusia yang unggul sekalipun. Setelah ia berhasil mempelajari dan mengembangkan kemampuannya sendiri. Sebagai contoh, dalam sebuah berita yang dilaporkan oleh The Guardian, sebuah robot yang menggunakan kecerdasan buatan (Artificial Intelligence), Alphazero, mengalahkan seorang juara catur dunia. Setelah robot tersebut mempelajari dan meningkatan kecerdasannya sendiri (Gibbs, 2017). Sebuah peristiwa yang belum pernah terjadi di abad-abad sebelumnya.

Studi Jeremy Heimans dan Henry Timms, memperlihatkan bagaimana manusia abad 21 memiliki kapasitas untuk membuat film, juga uang; untuk menyebar harapan atau gagasan; untuk membangun pergerakan; atau bahkan untuk menyebar ketidakbenaran dengan pengaruh yang cukup besar. Semua terasa lebih mudah dari tahun-tahun sebelumnya. Karena teknologi telah berubah (Heimans, Jerremy and Timms, 2018).

Lajunya perubahan yang ada, pada akhirnya mendapat pengaruh yang besar juga pada tatanan kehidupan umat Kristen yang juga adalah bagian tak terpisahkan dari keberlangsungan kehidupan. Sebagai contoh, bila dahulu, ibadah selalu bertatap muka, sekarang ibadah tidak harus selalu bertatap muka secara langsung. Cukup menggunakan telepon pintar atau komputer yang dilengkapi sambungan internet, ibadah dapat dilaksanakan secara virtual.

Pendidikan, secara umum juga mengalami perubahan yang hampir serupa. Hadirnya platform digital seperti Ruang guru, Zenius Education, adalah bukti bahwa pendidikan digital semakin berkembang. Sesuatu yang tidak akan dijumpai di abad sebelumnya.

Tidak hanya itu, YouTube, yang dominasinya semakin tak terhentikan, juga dibanjiri dengan video-video pembelajaran, dari yang tidak bermutu, hingga yang diisi oleh Professor dan para ahli. Dengan koneksi internet yang memadai, seseorang dapat mengakses video-video berkualitas di TED. Meski demikian, internet dan segala kemudahannya, juga perlu diikuti dengan sikap kritis dalam mencerna sesuatu. Maka, peringatan dari Tom Nichols tentang bahaya penyebaran pengetahuan yang keliru melalui internet, juga perlu dipertimbangkan dengan serius (Nichols, 2018).

Pada akhirnya, kemajuan ini, secara khusus menjadi sebuah peluang sekaligus tantangan bagi Pendidikan Kristen. Karena bagaimanapun, menurut penulis, pendidikan adalah instrumen yang olehnya 
manusia dibentuk, harus menyesuaikan dengan situasi temporal. Belum lagi, abad 21, bukan hanya menyimpan cerita kemajuan yang dicapai oleh manusia. Ada banyak masalah menantang, seperti yang akan dibahas kemudian, juga tidak bisa diabaikan begitu saja. Kemajuan dan tantangan ini, yang akan mempertanyakan bagaimana Pendidikan Kristen menyikapinya, dan apa relevansinya.

Secara lebih lugas, Yuval Noah Harari, melempar dengan sebuah pertanyaan: What should we teach that baby that will help him or her survive and flourish in the world of 2050 or of the twenty-second century? (Harari, 2018). Pertanyaan ini, sangat substansial.

\section{Metode Penelitian}

Tulisan ini, akan menggunakan penelitian pustaka. Dalam pada itu, penulis akan mengkomparasi berbagai literatur: buku, jurnal, dan artikel. Dengan demikian, seperti yang disebutkan Mestika Zed, penelitian ini akan bercorak: pertama berhadapan langsung dengan teks atau data angka, bukan dengan lapangan atau saksi mata, berupa kejadian, orang atau bendabenda lain. Kedua, data bersifat siap pakai, artinya peneliti tidak pergi ke mana-mana, kecuali hanya berhadapan langsung dengan sumber yang sudah ada di perpustakaan. Ketiga, data di perpustakaan umumnya adalah sumber data sekunder, atau diartikan bahwa peneliti memperoleh data dari tangan kedua bukan asli dari tangan pertama di lapangan. Keempat, kondisi data di perpustakaan tidak dibagi oleh ruang dan waktu (Zed, 2004).

Namun demikian, penulis juga tidak akan mengabaikan beberapa narasinarasi yang ditemukan dalam kehidupan sehari-hari. Terutama narasi yang berjalinkelindan dengan Pendidikan Kristen.

\section{Pendidikan Kristen}

Sebelum mengelaborasi lebih lanjut, diperlukan sebuah afirmasi dan pemahaman mengenai definisi Pendidikan Kristen dalam tulisan ini. Selain perlunya memetakan bagaimana dan di mana proses berlangsungnya.

Mendefinisikan Pendidikan Kristen merupakan sebuah langkah yang kompleks. Ada banyak hal yang memengaruhi dan turut membentuk pengertian akan Pendidikan Kristen. Satu di antaranya adalah pandangan warisan. Maksud dari pandangan warisan adalah pandangan yang diyakini tanpa membaca buku atau kajian terbaru, tetapi diterima begitu saja dari orangtua atau pandangan umum.

Untuk lebih jelas, berikut pemaparannya. Dalam studinya, Justita Vox Dei Hattu, menemukan bahwa 
pengertian Pendidikan Kristen yang dianut sebagian besar orang, hanya dibatasi pada Pendidikan Agama Kristen yang diajarkan dalam jenjang sekolah. Juga diikuti dengan sikap bahwa Pendidikan Kristen secara otomatis dikaitkan dengan menjadi guru agama. Hattu, juga menandaskan bahwa sebagian orang memandang bahwa Pendidikan Kristen lebih gampang ketimbang studi teologi (Hattu, 2019).

Selain itu, khususnya di Indonesia, Sejarah pendidikan agama Kristen di Indonesia berkaitan dengan sejarah kolonialisme bangsa-bangsa Eropa. Dampak dari keterkaitan dengan kolonialisme tersebut, masih bisa dirasakan sampai sekarang (Lauterboom, 2019). Salah satu yang paling menonjol, adalah pemahaman bahwa apa yang dikatakan Pendeta semuanya benar. Setidaknya temuan ini, masih sering penulis temui di beberapa tempat, khusunya di gereja-gereja yang diperkenalkan oleh misionaris Eropa. Di masa itu, para misionaris yang datang juga berperan ganda sebagai pengajar sekaligus penginjil.

Keadaan tersebut, yang mungkin juga menjadi cikal-bakal terjadinya polarisasi Pendidikan Kristen yang ambigu. Karena dalam praktiknya, gereja menjadi pilar untuk didirikannya sekolah, tetapi secara bersamaan batasan-batasan antara Teologi dan Pendidikan Kristen semakin jelas. Bukankah belajar Teologi Sistematika, Biblika, dan lain-lain, juga adalah proses Pendidikan Kristen?

Dalam pada itu, melalui tulisan ini, penulis akan mendefinisikan Pendidikan Kristen dengan menggambungkan pemahaman dari beberapa pendidik, atau para pelaku pendidikan. Penulis bahkan menggunakan pemahaman dari para ahli yang tidak memiliki concern pada Pendidikan Kristen, dengan alasan ingin melihat spektrum yang lebih luas. Sambil memadukan dengan beberapa poin tertentu dari Justita Vox Dei Hattu, yang serius menekuni perkembangan Pendidikan Kristen di Indonesia.

Pengertian pendidikan, bila mengacu pada salah satu buku yang menjadi bestseller di New York Times, yang berjudul Educated, diartikan begitu sederhana tetapi ringkas, yakni "Transformation. Metarmophosis. Falsity. Betrayal.” (Westover, 2018). Kata transformasi, dalam tulisan ini, yang akan menjadi perhatian utama dalam mengartikan pendidikan.

Atau jika ditarik lebih jauh dan lebih jelas, seperti yang ditandaskan oleh Grace Y.S, meski ia menggunakan kata lain, "Sekolah," tulisnya, "bukan hanya untuk menimba ilmu pengetahuan dan 
keterampilan, namun juga untuk menempa, membentuk, mengubah, dan menguatkan karakter insan-insan, generasi penerus bangsa.” (Shiang, 2018).

Selain itu, seperti yang dituliskan Justitia Vox Dei Hattu sebelumnya, maka lanjutannya adalah menegasi polarisasi Pendidikan Kristen antara gereja dan sekolah (Hattu, 2019). Itulah sebabnya, dari pengertian di atas, kata sekolah, keluarga, atau gereja, juga tetap terkait dengan pendidikan, dalam hal ini Pendidikan Kristen.

Dalam pada itu, dalam tulisan ini, istilah pendidikan akan merujuk pada upaya untuk menanamkan nilai dan pengetahuan, yang bertujuan untuk mentransformasi seseorang. Sehingga, ketika digabung menjadi pendidikan Kristen, upaya mentransformasi tersebut, hanya dibatasi pada proses mentransformasi yang diselenggarakan oleh komunitas Kristen. Baik lembaga, perseorangan, keluarga, atau gereja secara langsung.

Jadi, dalam tulisan ini, ketika menyebut Pendidikan Kristen lokus dan ruang kerjanya tidak bisa hanya dibatasi dalam lingkungan gereja dan sekolah. Justru, yang menjadi penggerak utama dalam proses berlangsungnya Pendidikan Kristen, adalah keluarga. Seperti yang diungkapkan oleh Desi Sianipar, "Keluarga, " tulisnya, "adalah penentu bagi ketahanan individual dan masyarakat sebab sebagai unit terkecil dalam masyarakat..." (Sianipar, 2020).

\section{Tantangan di Abad-21}

Selain kemajuan, abad 21, juga menyimpan banyak banyak masalah. Semua masalah ini, yang pada akhirnya membentuk rantai dan memberi pengaruh dalam kehidupan manusia. Pendidikan Kristen, pada akhirnya merasakan pengaruh tersebut. Yang juga menuntut sikap dalam menghadapi dan memberikan solusi pada masalah tersebut.

Dengan menggunakan pemaparan Yuval Noah Harari dan pemikir lain, penulis akan mencoba menguraikan beberapa tantangan zaman yang saat ini sedang dihadapi umat manusia dan keutuhan ciptaan. Masalah-masalah tersebut, tertuang dalam buku Harari, 21 Lessons for $21^{\text {st }}$ Century, maupun ceramahceramahnya yang tersebar luas di YouTube.

Seperti yang dikemukakan sebelumnya, hal ini dilakukan untuk melihat perubahan dan tantangan apa saja yang sedang dihadapi umat manusia sekarang ini, yang juga akan memberi pengaruh dalam dunia pendidikan. Selain itu, hemat penulis, masalah tersebut juga 
sangat mendesak. Mungkin, ada beberapa pihak bisa mengatakan bahwa isu-isu yang akan dipaparkan selanjutnya, tidak relevan dengan keadaan di Indonesia, tetapi bagaimanapun juga, Indonesia tidak bisa lepas dari pengaruh global. Namun, sebisa mungkin masalah yang menurut penulis tidak relevan dalam konteks Indonesia, akan diabaikan.

Harari, yang dalam berbagai kesempatan memperkenalkan diri sebagai sejarawan, cukup sering mengatakan bahwa tantangan zaman saat ini, benarbenar berbeda. Sebagai contoh, dengan mengacu pada data dari Global Burden of Disease, Injuries and Risk Factors Study 2013 dari Stpehen Adams, Harari menandaskan, "In 2010 famine and malnutrition combined killed about 1 million people, whereas obesity killed 3 million."'(Harari, 2018).

Meskipun mungkin di negara lain yang masih mengalami kelaparan dan menjadikan tantangan ini tidak relevan, akan tetapi hal ini menunjukan bahwa perubahan dunia benar-benar berbanding terbalik dengan zaman sebelumnya.

Selanjutnya, terkait permasalahan serius yang dihadapi oleh manusia, penulis memilih tiga dari sekian banyak masalah yang juga didaftarkan Harari dalam bukunya. Pertama adalah Climate Change.
Di Indonesia, sebagai negara kepulauan, dampak kenaikan permukaan air laut dengan rata-rata $1,7 \mathrm{~mm} /$ tahun sejak 1875 , tetapi sejak 1993 menjadi rata-rata 3 $\mathrm{mm} / \mathrm{tahun}$, atau lebih dari satu inci per dekade, dengan prospek laju kenaikan bisa lebih tinggi lagi, telah dirasakan. Demikian dampak negatif hasil panen akibat kenaikan suhu global rata-rata (Magdoff \& Foster, 2018).

Menurut hemat penulis, perubahan iklim, dalam kasus tertentu seperti kenaikan suhu global, juga disebabkan oleh ulah manusia. Penebangan pohon yang semakin masif dilakukan dan disengaja, pada akhirnya turut memberikan pengaruh bagi perubahan iklim, seperti berkurangnya sumber oksigen. Pendidikan Kristen, harus memberikan peran penting dalam hal ini.

Lalu, tantangan yang ke-dua adalah War. Dalam bukunya yang berjudul 21 Lessons for The $21^{\text {st }}$ Century, Harari membahas khusus terkait perang, di bab 11. Ancaman perang dalam skala besar, memang tidak begitu terasa di Indonesia. Apalagi dalam konteks pedesaan, yang menghadapi pergulatan tersendiri. Namun, pada hakikatnya, baik perang menggunakan senjata canggih atau perang tradisional sama-sama bermuara pada tindak kekerasan yang bertujuan melukai atau membunuh orang lain. 
Indonesia punya catatan yang panjang mengenai tindak kekerasan ini, mulai dari masalah di Poso hingga tindak kekerasan yang terjadi dalam skala kecil. "Poso," misalnya dalam penelitian McRae, "menjadi tempat berlangsungnya konflik antar-agama di era Indonesia pascaotoriter." (McRae, 2016). Dengan demikian, maka masalah ini, patut untuk menjadi perhatian serius Pendidikan Kristen, dalam upayanya membentuk manusia yang mencintai dan menggagas perdamaian.

Sementara untuk tantangan yang ke-tiga, terkait dengan pendidikan itu sendiri. Hal tersebut dibahas khusus oleh Harari, dalam pembahasannya mengenai pendidikan, dengan mengatakan bahwa ke depan, ada banyak pengetahuan yang tidak akan relevan bagi dunia pekerjaan. Semuanya akan diganti oleh robot yang dilengkapi kecerdasan buatan. Lalu, Harari menyarankan demi mengantisipasi hal tersebut, manusia harus terus mengembangkan diri, dengan mempelajari hal-hal yang baru (Harari, 2018).

Pada akhirnya, situasi tersebut semakin menyeret pendidikan pada sikapnya yang akan semakin sulit dijangkau oleh kelompok tertentu. Jangankan mempelajari hal-hal yang baru, bahkan sekadar mengakses literasi dasar (membaca dan menulis) sudah sangat kesulitan.

Untuk itu, penulis melihat tantangan lain yang menjadi masalah serius bagi dunia Pendidikan Kristen, yakni jangkauan pendidikan yang masih belum bisa menjangkau kaum tertentu. Apalagi, pendidikan kini semakin tidak berdaya di bawah kemahakuasaan uang (Sasongko, 2019). Itulah sebabnya, banyak orang yang akhirnya tidak menempuh pendidikan dengan alasan tidak mampu membayar biaya pendikan.

Jika pendidikan masih sulit dijangkau, lalu, tujuan pendidikan sebagai proses transformasi masih akan begitu sulit terwujud. Apalagi, jika melihat konteks Indonesia, pendidikan masih memegang peran penting dalam dunia pekerjaan, karena pendidikan juga memengaruhi keahlian seseorang terhadap sebuah bidang, maupun hanya sekadar sebuah syarat dalam proses pencarian pekerjaan.

Ke-tiga masalah ini, tidaklah mewakili secara keseluruhan masalah yang dihadapi oleh manusia di abad 21. Masih banyak masalah lain, yang juga memerlukan perhatian serius. Apalagi jika terkait Pendidikan Kristen, masih banyak masalah yang juga tidak boleh dianggap remeh. Dalam pada itu, beracu ketiga masalah yang diuraikan di atas, selanjutnya 
tulisan ini akan mencoba memberikan tawaran mengenai langkah yang dapat ditempuh pendidikan Kristen untuk tantangan di abad 21.

\section{Menentukan Arah}

Dengan sederet masalah yang telah dipaparkan sebelumnya, lalu bagaimana sikap Pendidikan Kisten? Pendidikan Kristen mempunyai tugas suci untuk memperjuangkan manusia lainnya mewujudkan jati dirinya sebagai ciptaan menurut gambar dan rupa Allah. Dengan demikian, selanjutnya akan dipaparkan beberapa langkah-langkah yang dapat diambil, untuk mengatasi masalah-masalah tersebut.

Tawaran yang diajukan untuk mengatasi masalah-masalah yang sudah dipaparkan sebelumnya, beracu pada kehidupan Yesus dan tradisi Kristen itu sendiri. Dengan berlandaskan hal tersebut, maka selanjutnya, akan diperoleh sikap dan cara mengatasi: perubahan iklim, ancaman bahaya perang, dan kesulitan dalam akses pendidikan.

\section{Yesus: Sang Guru}

Pendidikan Kristen, dalam mengambil sikap terhadap sebuah masalah, harus berdasarkan pada Kitab Suci, yang akhirnya akan berbenturan dengan situasi temporal. Dalam banyak hal, situasi temporal, memiliki banyak perbedaan dengan masa ketika Alkitab ditulis. Tak bisa dihindari, pada akhirnya muncul pertanyaan: akankah berpegang teguh kepada iman tradisional kita untuk merumuskan metode pendidikan? Atau, tradisi Kristen sudah usang, sekarang waktunya kita menyusun sebuah tatanan yang baru, tanpa harus menggunakan Alkitab.

Menurut hemat penulis, Alkitab, memang bukanlah panduan lengkap tentang pendidikan. Namun, juga tidak bisa dimungkiri, bahwa Alkitab juga memberikan cukup banyak wawasan mengenai pendidikan. Casthelia Kartika, dalam tulisannya, mengacu dari pemikiran Origenes, bahkan menunjukan bahwa pembacaan Kitab Suci adalah sebuah pedagogi ilahi (Kartika, 2019). Selain itu, mengutip Herman Horne, Ismail, dan Jack Seymour, Binsen S. Sidjabat mengusulkan bahwa jika pendidikan Kristen pada masa kini hendak memperkaya pemahaman warga gereja, maka patutlah cara Yesus mendidik dan mengajar mendapat perhatian cermat (Sidjabat, 2019).

Dalam pada itu, tulisan ini akan mencoba menelisik "gagasan-gagasan" yang terdapat dalam Alkitab secara khusus kehidupan Yesus, untuk dijadikan sebagai tawaran bagi Pendidikan Kristen dalam menanggapi ke-tiga tantangan abad 21, yang sudah dipaparkan sebelumnya. Meski 
demikian, tulisan ini, hanya akan membatasi dan menitikberatkan penyelidikan Alkitab pada kehidupan Yesus, dan juga pada beberapa warisan teologi Kristen.

Tidak bisa dimungkiri, Yesus adalah seorang guru. Namun, pendapat ini, tidak boleh diartikan bahwa dengan mengatakan bahwa Yesus adalah seorang guru, mengabaikan ke-Allah-an Yesus. Bagaimanpun juga, pendapat tersebut tidak bisa diterima. Yesus, dalam banyak hal, dapat dikatakan sebagai guru. Tetapi, Ia tidak semata-mata, hanyalah seorang guru, dengan tujuan mendidik orang. Yesus melampaui hal tersebut.

Dalam banyak kesempatan, Yesus ditampilkan sebagai sosok pengajar yang berkharisma. Tak jarang, para murid juga memanggil Yesus sebagai seorang Rabbi. Kata Rabbi sendiri, meskipun masih menimbulkan banyak perdebatan dalam penerjemahannya, namun kata itu sendiri menurut penulis, hanya pantas disematkan kepada sosok yang dianggap mampu mengajar.

Sebagai contoh, dalam kitab Yohanes 1:38, King James Version menuliskan, "Then Jesus turned, and saw them following, and saith unto them, What seek ye? They said unto him, Rabbi, (which is to say, being interpreted, Master,) where dwellest thou?" Penafsiran lain, menurut Jeremmy Duff, kata Rabbi yang dalam bahasa Yunani menjadi $\delta เ \delta \alpha ́ \sigma \kappa \alpha ́ \lambda \omega \varsigma$ bisa diartikan sebagai teacher (Duff, 2005). Akan tetapi, menurut hemat penulis, terlepas dari perbedaan penggunaan master dan teacher, kedua kata ini merujuk kepada seseorang yang memiliki keahlian tertentu. Oxford Dictionary dengan jelas mengartikan kata master sebagai, "person who is very skilled." Sedangkan kata “teacher, ” langsung merujuk kepada sosok guru. Hal ini, cukup untuk membuktikan bahwa Yesus juga adalah seorang guru. Selaras dengan yang dituliskan Jeniffer F.P. Pelupessy Wowor yang mengatakan, "Jesus Himself was a teacher, and He commanded us to be a community committed to teaching (Wowor, 2016). Pernyataan tersebut benar bila melihat apa yang dilakukan Yesus selama Ia hidup. Yesus adalah guru yang menempuh jalan yang berbeda dengan guru-guru yang ada pada zaman-Nya.

Dalam pada itu, dengan melihat teladan yang Yesus sudah lakukan sebagai seorang guru, maka akan didapatkan metode apa saja yang dapat berjalinkelindan dengan Pendidikan Kristen sekarang ini, dengan segala tantangan yang sedang dihadapi, dan sudah dipaparkan sebelumnya. 
Pendidikan Krsiten: Menjangkau dan Membuka Diri

Kesulitan akses pendidikan, adalah masalah bersama. Kisah tentang ketidakmampuan untuk mengakses pendidikan, terlalu sering didengarkan. Bukan hanya yang terliput media. Kisah tersebut, bisa datang dari orang-orang terdekat. Alasannya, tidak jauh-jauh dari himpitan ekonomi. Sementara di sisi yang lain, pendidikan membutuhkan biaya yang cukup mahal.

Sebagai contoh, selain pengalaman penulis sendiri yang juga kesulitan saat sekolah, penulis pernah bertemu dengan seorang anak usia Sekolah Menengah Atas, yang memiliki impian untuk menjadi seorang seniman. Namun, oleh karena terkendala biaya dan kondisi ekonomi keluarga, ia mengatakan terpaksa menyimpan mimpi itu terlebih dahulu. Seorang teman yang lain, pernah bercerita tentang pengalamannya saat masih sekolah. Orangtuanya bahkan pernah harus menjual dinding papan rumah mereka, hanya untuk dipakai membayar biaya sekolah.

Pendidikan Kristen mengambil peran penting dalam menuntaskan masalah ini. Namun, sering kali, yang terjadi justru hal sebaliknya. Masih banyak sekolah
Kristen yang terkenal mahal, dan hanya dapat dijangkau oleh kelompok ekonomi menengah ke atas. Lalu, jika demikian, bagaimana dan apa langkah yang harus ditempuh, agar permasalahan ini bisa ditangani? Pendidikan Kristen, harus kembali menilik kehidupan Yesus, dan mencoba menerapkan nilai-nilai yang telah diteladankan-Nya. Begini penjabarannya.

Dalam bukunya yang berjudul Jesus Before Christianity Albert Nolan menuliskan, "John the Baptist preached to sinners. Hanina ben Dosa exorcised evil spirit from them. But Jesus identified with them. He went out of his way to mix socially with beggars, tax collectors and prostitutes (Nolan, 2001).” Dalam pandangan penulis, meskipun hasil akhir dari yang yang dilakukan Hanina ben Dosa tetap sebuah tindakan yang baik, namun Nolan berupaya membedakan Yesus dengan tokoh-tokoh yang lain. Yohanes dan Hanina ben Dosa, menjadikan orang-orang tertentu sekadar objek pelayanan, tetapi Yesus merangkul dan menyatu dengan mereka.

Di zaman yang serba digital ini, sikap untuk saling membatasi diri kian meruncing. Sikap rasis, juga pada akhirnya menjadi semakin tinggi (Kendi, 2019). Orang hanya ingin bergaul atau berinteraksi dengan serius jika dalam banyak hal memiliki kesamaan. Untuk mengubah dan menanamkan nilai-nilai 
untuk sikap yang mau membuka diri, tentu juga harus dimulai dari keluarga dan juga sekolah.

Pendidikan Kristen, jika memang harus mengacu pada pribadi Yesus, harusnya berani untuk membuka diri dan menyapa mereka yang dianggap "asing" dan terpinggirkan. Kesiapan membuka diri untuk menyapa semua orang memang harus ada dalam pendidikan Kristen. Melihat begitu banyaknya orang yang tidak mendapatkan akses pendidikan, harusnya menjadi sebuah peluang untuk Pendidikan Kristen untuk menjangkau orang-orang tersebut.

Pendidikan Kristen telah memiliki landasan untuk menjawab permasalahan yang terkait dengan kesulitan mendapat akses pendidikan. Menjadi Kristen, berarti mengikuti jalan Yesus. Jika, kisah Zakeus dibaca sebagai sikap terbuka Yesus untuk memberikan kesempatan kepada Zakeus untuk belajar, maka, langkah pertama yang harus dilakukan Pendidikan Kristen, adalah membuka diri. Memberikan akses bagi orang yang kesulitan mengakses pendidikan.

Sayangnya, Pendidikan Kristen belum berani melangkah dan menginvestasikan sumber daya yang ada pada penjangkauan pendidikan. Gereja, yang menjadi pilar utama bagi pengembangan Pendidikan Kristen, juga hanya terjebak pada soal-soal internal. Hal ini terbukti dengan banyaknya gereja yang lebih mementingkan pembangunan gedung yang mewah, penggunaaan eksterior yang menawan, dan akhirnya kurang memberi perhatian pada pendidikan.

Masalah ketidakmerataan akses pendidikan, akan terselesaikan bila Pendidikan Kristen memiliki keberanian untuk mencurahkan daya, waktu, dan dananya; untuk kepentingan banyak orang. Teristimewa mereka yang terbatas karena keuangan dan kesempatan.

Di masa sekarang, seperti yang ditandaskan oleh Baharrudin dan Makin bahwa belajar akan lebih bermakna bagi anak jika mereka mengalami apa yang dipelajarinya bukan sekadar mengetahuinya (Baharuddin \& Makin, 2017). Maka dapat ditarik kesimpulan, dengan membuka diri dan menjangkau mereka yang terpinggirkan, secara bersamaan kita sedang mendidik diri sendiri untuk serupa dengan Kristus. Prinsip ini, pernah penulis temukan dalam sebuah sekolah yang menggunakan subsidi silang. Orangtua yang memiliki penghasilan cukup, akan membayar biaya cukup besar, dengan persetujuan yang disepakati tanpa paksaan. Sebaliknya, anak-anak yang kurang mampu, bisa 
membayar semampunya. Bahkan jika tidak mampu sama sekali, tidak perlu membayar.

Prinsip ini tentunya sangat bagus, meski baru diterapkan dalam ruang lingkup kecil. Pendidikan Kristen dapat mengembangkan hal ini secara lebih luas, dengan mendukung orang-orang yang tak memiliki kesempatan dan kemampuan untuk mengakses pendidikan.

\section{Pendidikan Kristen: Compassion!}

Bila harus jujur, kekerasan atas nama agama masih sering terjadi. Termasuk dalam agama Kristen. Sebagai contoh, Lady Paula R. Mandalika menuliskan tentang kerusuhan di Halmahera yang melibatkan dua agama. Yang mengejutkan, Mandalika menuliskan bahwa beberapa jemaaat yang mengungsi melihat situasi kerusuhan yang dihadapi sebagai suatu jalan yang harus mereka lalui sebagai seorang pengikut Kristus. Beberapa ayat dalam Alkitab bahkan dijadikan sebagai pendukung. Salah satunya adalah ketika Israel berjalan keluar dari tanah Mesir menuju tempat perjanjian. Dari hasil wawancara dengan seorang pengungsi di Daeo, Mandalika menuliskan, "Menurut mereka, orang Kristen harus menderita dan berkorban demi Kristus.” (Mandalika, 2019).

Pemahaman seperti di atas, menjadikan Alkitab seperti mendukung tindak kekerasan. Namun, yang menjadi masalahnya, apakah Alkitab menglegitimasi tindak kekerasan? Penulis, dengan tegas mengambil sikap, bahwa Alkitab tidak pernah mendukung tindak kekerasan. Yang menjadikan Alkitab seolah-olah mendukung tindak kekerasan adalah sudut pandang penafsir. Jika mengikuti metode penafsiran Heiddeger, seperti yang dijelaskan oleh Budi Hardiman, hal ini bisa diartikan sebagai pra-pemahaman (Hardiman, 2015). Sebelum membaca teks Alkitab, atau teksteks lainnya, seseorang tidak pernah lepas dari pengalamannya di saat itu. Pembaca yang cenderung ingin berdamai, ketika membaca kisah-kisah pengampunan, akan semakin memperkokoh prapemahamannya, bahwa Alkitab memang mengajarkan pengampunan. Demikian dengan teks yang seolah-olah mendukung tindak kekerasan, akan dipandang dengan kacamata kasih.

Lalu, bagi seseorang yang cenderung ingin membalas dendam dan mendukung kekerasan, akan mencari ayatayat pendukung untuk memperkokoh prapemahamannya. Hasil pembacaan tersebutlah, yang akan membentuk pemahamannya.

Terlepas, dari prinsip penafsiran Heiddeger yang dipaparkan oleh Hardiman, penulis berpandangan bahwa 
Alkitab mengajarkan kasih. Ini semakin terang, jika menilik pengajaran Yesus Kristus. Tak ada ruang untuk melegetimasi kekerasan.

Dengan tepat, Merry Kolimon menandaskan, "Biblical tradition teach us that God created the world and human beings in an orderly manner and wants the member of God's creation to live in harmony and to care of one another." (Kolimon, 2015). Melalui pernyataan tersebut, diketahui bahwa tujuan Tuhan menciptakan manusia untuk saling peduli satu sama lain.

Bahkan, jika melihat kehidupan Yesus, seperti yang ditegaskan oleh Nolan, akan ditemukan sebuah fakta bahwa Yesus begitu mengasihi orang lain, termasuk orang-orang yang dianggap tidak pantas untuk dikasihi. Dalam penyelidikannya, Nolan, menemukam bahwa kata "compassion” dalam Bahasa Inggris, masih begitu lemah untuk mengartikulasikan sebuah emosi yang memotivasi Yesus. "Splagchinzomai" adalah kata kerja dalam Bahasa Yunani yang digunakan dalam teks tersebut berasal dari kata benda "splagachon," yang berarti usus atau hati, hal tersebut dapat dikatakan sebagai emosi yang terlahir dari hati yang terdalam (Nolan, 2001).
Alkitab, secara khusus dalam Matius, Markus, Lukas dan Yohanes, merupakan sumber yang menjadi rujukan, tentang sikap bela rasa Yesus. Yesus bukan hanya peduli terhadap orang miskin dan kaum yang tertindas, tetapi juga kelompok orang yang sering dianggap pendosa dan sumber masalah dalam masyarakat.

Pendidikan yang menanamkan sikap penuh bela rasa, akan menjadikan manusia menjadi peduli dengan orang lain. Peperangan dan tindak kekerasan lainnya, tidak harus terjadi jika seseorang memiliki sikap bela rasa. Karena, Compassion, menurut James Martin, SJ., adalah "turut mengalami" dan "turut menderita." (Martin, 2018).

Manusia yang memeroleh pendidikan yang berorentasi pada sikap bela rasa, akan menimbang tentang pengalaman dan derita yang akan dialami oleh orang lain, melalui olah rasa dan olah pikirnya secara pribadi. Atau, sebelum melakukan tindak kekerasan kepada orang lain, ia terlebih dahulu merasakan apa yang akan dialami orang lain.

\section{Pendidikan Kristen: Peduli terhadap Lingkungan}

Sepertinya, jika menilik buku-buku teologi sistematika, teologi Kristen begitu antroposentris ketika menempatkan manusia sebagai ciptaan yang lebih utama. 
Ini dapat ditemukan dalam tulisan Berkhof, yang menuliskan, "Manusia bukan saja mahkota dari seluruh ciptaan Allah, tetapi juga objek khusus pemeliharaan Allah" (Berkhof, 2013). Tentunya, hal ini sah-sah saja. Namun, jika dimaknai bahwa manusia bebas melakukan apa saja terhadap cipataan lain, justru menempatkan manusia pada sikap yang arogan terhadap alam. Maka, tidaklah mengejutkan ketik the Public Religion Research Institute (PRRI) dan the American Academy of Religion (AAR), menerbitkan sebuah survey mengapa orang-orang di Amerika Utara diperhadapkan dengan isu perubahan iklim, aturan lingkungan dan sains. Yang mengejutkan, banyak yang tidak menganggap serius mengenai isu perubahan iklim (Sasongko, 2016b).

Eksploitasi alam, sedang terjadi dalam skala yang cukup besar. Itulah sebabnya, perubahan iklim tidak dapat diprediksi dan sering terjadi. Maka, diperlukan sebuah sikap yang peduli terhadap lingkungan untuk menangani hal ini.

Sudah selayaknya, teologi Kristen menempatkan alam bukan hanya sekadar objek. Penulis sepakat dengan Saras Dewi, yang dengan lugas menandaskan bahwa fenomenologi lingkungan berarti bagaimana memahami ekosistem sebagai fenomena, bukan objek yang terlepas dari subjek dengan objeknya (Dewi, 2018). Hal ini, selaras dengan amanat Allah yang menyuruh manusia untuk memelihara ciptaan lain.

Pendidikan Kristen, menurut Sosawato Telaumbanua, jika ditilik dari Markus 16:15, juga bertanggungjawab untuk memberitakan Injil kepada seluruh makhluk. Kata makhluk, yang menggunakan kata ktisis, dapat diartikan sebagai makhluk atau ciptaan. Makhluk di sini mencakup manusia, hewan dan tumbuh-tumbuhan yang diciptakan oleh TUHAN (Telaumbanua, 2020).

Dengan demikian, pandangan keselamatan, juga perlu memandang keselamatan semesta sebagai agenda Allah. Atau, seperti yang dituliskan N.T Wright,

We have been right, deeply right, to think that Paul is vitally concerned with the salvation of human beings and all that goes with that: the reedeming death of Jesus, justification by grace through faith and so on. But we have been wrong to suppose that the only purpose was the salvation of humans---as it were, away from the world, away from the whole created order. (Wright, 2014).

Dengan perombakan pemahaman ini, harusnya sejak dini telah ditanamkan 
sebuah pemahaman tentang keselamatan semesta. Dengan demikian, maka manusia akan bertanggungjawab atas cipataan lain. Karena sering kali, seperti yang dituliskan oleh Nindyo Sasongko, "Problem selanjutnya dalam eskatologi klasik adalah antroposentris, berpusat pada manusia, dan ouranosentris, berpusat pada surga dan neraka." (Sasongko, 2016a).

Manusia, tidak boleh hanya berpikir soal surga yang akan datang, sehingga mengabaikan fakta kehidupan yang sedang berlangsung sekarang. Pendidikan Kristen, perlu untuk menanamkan pemahaman bahwa manusia juga bertanggungjawab terhadap ciptaan yang lain. Ada keterkaitan manusia, semesta, dan Sang Pencipta, yang olehnya manusia perlu menjaga alam dan ciptaan lain, demi keutuhan dan keselamatan semesta.

Pengajaran ini, perlu digaungkan teristimewa dalam kondisi sekarang di mana banyaknya manusia, termasuk yang beragama Kristen, sering menjadi pelaku utama dalam merusak alam. Entah itu menjadi pembuang sampah di sembarang, mencemari sungai, menjadi penebang pohon secara sembarang, dan lain-lain.

\section{Kesimpulan}

Abad 21, merupakan masa yang sangat ambigu. Kemajuan dan penemuan akan hal-hal baru, seperti kecerdasan buatan, berada di masa keemasannya. Namun, kemajuan tersebut, tetap meyisahkan banyak celah dan tantangan seperti bahaya perang, perubahan cuaca, dan juga keterbatasan akses pendidikan yang semakin mahal. Pendidikan Kristen, perlu memberikan solusi dalam menghadapi ancaman tersebut.

Setelah menelisik Alkitab, beberapa buku, dan jurnal; maka ditemukan bahwa untuk mencoba mengatasi permasalahan tersebut, diperlukan nilai-nilai dan prinsip yang sejalan dengan Yesus teladankan. Demikian juga dengan tradisi Kristen, perlu untuk dikaji kembali, dan diaplikasikan dalam laku hidup sehari-hari, secara khusus bagi Pendidikan Kristen. Bahaya perang, misalnya, diantisipasi dengan compassion. Demikian dengan perubahan cuaca, juga perlu untuk ditanamkan sikap yang peduli terhadap lingkungan. Lalu, untuk mengatasi kesulitan akan akses pendidikan, maka Pendidikan Kristen haruslah menjangkau dan membuka diri.

Tiga prinsip yang telah diajarkan oleh Yesus dan telah ada dalam tradisi Kristen tersebut, perlu untuk dimiliki oleh Pendidikan Kristen. Semuanya bisa dimulai dari keluarga. Seperti yang ditulis sebelumnya, Pendidikan Kristen tidak bisa 
hanya dibatasi pada sekolah dan gereja, maka penulis berpendapat bahwa ke-tiga nilai-nilai tersebut, harus ditanamkan terlebih dahulu dalam keluarga. Dalam pada itu, diperlukan kolaborasi dari semua pihak dan lembaga, untuk kelangsungan Pendidikan Kristen. Kolaborasi ini, akan mencetuskan langkah-langkah praktis dalam mewujudkan ke-tiga nilai-nilai tersebut.

Selain itu, Pendidikan Kristen, perlu untuk mengambil sikap serius dalam mengikuti teladan Yesus, dalam pelaksanaan Pendidikan Kristen. Menggunakan metode atau mengkomparasi prinsip lain, tentu bolehboleh saja. Namun, hal itu tidak boleh melupakan bahwa Pendidikan Kristen sudah semestinya dibangun dari kehidupan Yesus.

\section{Daftar Pustaka}

Baharuddin, H., \& Makin, M. (2017). Pendidikan Humanistik: Konsep, Teori, dan Aplikasi Praksis dalam Dunia Pendidikan. Ar-Ruzz Media.

Berkhof, L. (2013). Teologi Sistematika: Doktrin Manusia. Momentum.

Dewi, S. (2018). Ekofenomenologi: Mengurai Disekulibirium Relasi Manusia dengan Alam. Marjin Kiri.

Duff, J. (2005). The Element of New
Testament Greek. Cambridge University Press.

Gibbs, S. (2017). AlphaZero AI beats champion chess program after teaching itself in four hours. https://www.google.com/amp/s/amp.t heguardian.com/technology/2017/dec /07/alphazero-google-deepmind-aibeats-champion-program-teachingitself-to-play-four-hours

Harari, Y. N. (2018). 21 Lessons for the 21st Century. Vintage.

Hardiman, F. B. (2015). Seni Memahami: Hermeneutik dari Schleiermacher sampai Derrida. Kanisius.

Hattu, J. V. D. (2019). KETERKAITAN PENDIDIKAN KRISTIANI DI SEKOLAH DAN GEREJA. Indonesian Journal of Theology, 7(1), $25-45$.

Heimans, Jerremy and Timms, H. (2018). New Power: How Power Works in Our Hyperconnected World-----and How to Make It Work for You. New York: Doubleday. Doubleday.

Kartika, C. (2019). PEDAGOGI ILAHI: Pandangan Origen tentang Pengaruh Pembacaan Kitab Suci sebagai Pembentuk Nilai Kehidupa. Indonesian Journal of Theology, 7(1), 72-87. 
https://doi.org/10.1145/1390630.139 0641

Kendi, I. X. (2019). How to Be An Antiracist. Random Publisher.

Kolimon, M. (2015). Vulnerability, Resistance and Solidarity in the Household of God - Theological Reflection on People on the Move and Human Trafficking in Asia-Pacific. In Living Together in the Household of God: Asian Reflection (pp. 59-72). Chirstian Confrence of Asia.

Lauterboom,

M.

(2019)

\section{DEKOLONIALISASI}

\section{PENDIDIKAN AGAMA KRISTEN}

DI INDONESIA. Indonesian Journal

of Theology, 7(1), 88-110. https://doi.org/10.1017/CBO9781107 415324.004

Magdoff, F., \& Foster, J. B. (2018). Lingkungan hidup dan kapitalisme. Marjin Kiri.

Mandalika, L. P. R. (2019). Apakah Allah Membenarkan Kekerasan: Memepertanyakan Yosua 8 sebagai Teks Legitimasi Kekerasan dalam Konteks Halmahera. In Z. J. Ngelow (Ed.), Teologi Bencana: Pergumulan Iman dalam Konteks Bencana Alam dan Bencana Sosial (pp. 105-127). BPK Gunung Mulia.
Martin, J. (2018). Building a Bridge. HarperOne.

McRae, D. (2016). Poso: Sejarah Komprehensif Kekerasan Antar Agama Terpanjang di Indonesia Pasca Reformasi. Marjin Kiri.

Nichols, T. (2018). Matinya Kepakaran: Perlawanan terhadap Pengetahuan yang Telah Mapan dan Mudaratnya. Gramedia Pustaka Utama.

Nolan, A. (2001). Jesus Before Christianity. Orbis Books.

Sasongko, N. (2016a). Hidup Abadi: Pengharapan Seutuh Semesta? November, 1-12.

Sasongko, N. (2016b). "The Dearest Freshness Deep Down Things": International Review of Mision, 105(1), 86-103. https://doi.org/10.2307/j.ctt22nm9w3 .23

Sasongko, N. (2019). Arah Baru Pendidikan Kristiani di Indonesia? Sebuah Pengantar Editor. Indonesian Journal of Theology, 7(1), 1-6.

Shiang, G. Y. (2018). Sang Guru Duta. CV. Media Pusataka Utama.

Sianipar, D. (2020). PERAN PENDIDIKAN AGAMA KRISTEN DI GEREJA DALAM MENINGKATKAN KETAHANAN 
KELUARGA. Shanan, 4(1), 73-92.

Sidjabat, B. S. (2019). MERETAS POLARISASI PENDIDIKAN

KRISTIANI: Sebuah Pengantar tentang Arah Pendidikan Kristiani di Gereja, Akademia, dan Ruang Publik. Journal of Chemical Information and Modeling, $\quad 7(1), \quad 7-27$. https://doi.org/10.1017/CBO9781107 415324.004

Telaumbanua, S. (2020). PAK GEREJA DALAM KONTEKS

LINGKUNGAN HIDUP SUATU REFLEKSI TERHADAP MARKUS 16:15. Shanan, 4(1), 41-56.

Westover, T. (2018). Educated. Random Publisher.

Wowor, J. F. . P. (2016). Human Development and Christian Education. In A. S. Arualangi, Ronald. Harmakaputra, Hans A. Sasongko, Nindyo. Wilar (Ed.), Dari Disabilitas ke Penebusan: Potret Pemikiran Teolog-Teolog Indonesia (pp. 59-78).

Wright, N. . (2014). Surprised by Scripture: Enganging Contemporary Issues. HarperOne.

Zed, M. (2004). Metode Penelitian Kepustakaan. Yayasan Obor. 